\title{
THE EFFECT OF AUTHENTIC MATERIALS ON THE NINTH GRADE STUDENT'S READING COMPREHENSION AT SMP NEGERI 4 KOTA TANGERANG
}

\author{
1Fuji Devi Riani ${ }^{2}$. Yudhie Indra Gunawan ${ }^{3}$ Imtihan Hanim \\ ${ }^{123}$ English Education Study Program \\ Teachers Training and Education Faculty \\ Muhammadiyah University of Tangerang \\ E-mail: ${ }^{1}$ fujidevirianiwahyu@gmail.com ,2yudhie.indra@umt.ac.id, ${ }^{3}$ imtihan_hanim@umt.ac.id,
}

\begin{abstract}
This research was conducted at SMPN 4 KOTA TANGERANG which took place from July to August. The sample consisted 76 students from ninth grade which devide into two classes, experimental class (IX.3) and controlled class (IX.4).Based on the observation, some of students feel that learning of English, especially in reading is difficult subject compared to other lessons. So, the researcherss conduct research with used the Authentic Material with the aim in this research is to find and know whether that authentic material's effect or not on students' reading comprehension. This research used a quantitative method with a quasiexperimental design. In collecting the data, the researcherss gave pre-test and post-test on both classes with mulitiple choice questions that had been tested for validity and reliability before and in analyzing the data the researchers used t-test. Hyphothesis test result as the degree of significant $5 \%$ indicates that pre-test done before treatment is $\mathrm{T}_{\text {count }}(1,22982)<$ $\mathrm{T}_{\text {table }} 1,992543$, so $\mathrm{H}_{0}$ is accepted and $\mathrm{H}_{1}$ is rejected or there is no significant effect from experimental class and the controlled class before giving a treatment. It was found that posttest done after treatment is $\mathrm{T}_{\text {count }}(2,24132)>\mathrm{T}_{\text {table }} 1,992543$, so $\mathrm{H}_{0}$ is rejected and $\mathrm{H}_{1}$ is accepted. The result of this research shows that there is significant difference on students' reading comprehension by using authentic materials.Therefore, it can be interpreted that teaching reading by using authentic materials can increase the students' comprehension.
\end{abstract}

\section{Keyword: Reading, Reading Comprehension, Authentic Material.}

\section{INTRODUCTION}

English as International language is popular in the world, so that English is one of the important languages. As, Baugh and Cable (2005) stated that in various countries in the world, English is one of the most important to use. However, the use of English as a second language or foreign language, does not affect each other, even to the present progress of English continues to grow in various corners of the world. Thus, English is spreading around the world, it has achieved its global status as a result English is very dominating and influencing, in the aspects of life such as technology, business, music, film, politics, commerce, industry, services, economy, social, education, culture, and so on.

In Indonesia, The fast development of English is demanding this nations to be able to compete in various fields, so the improvement of human resources should take precedence. Any pattern of improvement and competitive strategy should be well structured. Sufficient knowledge is needed that can be exploited in the face of all the demands of world 
Globish (An English-Indonesian journal for English, Education and Culture

Vol. 10, No.2, July 2021,

P-ISSN: 2301-9913, E-ISSN: 2597-9132

DOI: http://dx.doi.org/10.31000/globish.v7i2

development. Consequently, English is one of important subjects and as the first foreign language that should be learned where in this modern era could be given positive impact to the generation.

The government and various related people who participate as mediator in developing English language proficiency of each child with English language in every educational both state-owned and private it is starting from elementary school level, junior high school, senior or vocational high school and until university. Where junior high school is a level needs to be taken within 3 years and who learn English is an obligation to best achievment.

In learning about English, there are four language skills that should be learned by students, there are: listening, speaking, reading, and writing. These four aspects are of course interrelated, although there are significant differences in the process. The students can learn the skill easier and more effective while learnt the language component. Students are guided to continue to learn and to live the principle of the four skills. Where reading is an initial process that is very necessary in exploring language skills. From Dakowska (2005, p.191) states," nowdays that reading is a highly interactive process". He also added that the reader build the ideas from the reading material based on the their own knowledge or ability and also experience. The interaction must continue to be construct to reach understanding in the right perspective. However, Reading is one of the basic skill in second or foreign language learning. Reading is activity to find out information from written material, such as: text book, newspaper, magazine, internet and other source.

Based on the observation interview to the teacher in November 30, 2018 at SMPN 4 KOTA TANGERANG, the researchers found that some problems in reading activities for students are: Firstly, The students havelimited of vocabulary. So, they do not understand the meaning of words on the text. The second thing is every student rarely reads books in English, which makes them more difficult to understand every word contained in a text. The third, each student has different background knowledge. The differences background of this different knowledge are caused by some students perform additional learning activities outside the home and school hours, such as: conducting private lessons, or taking additional extracurricular activities provided at the school. Then, every student feels that English is a very difficult subject compared to other lessons, because in English, writing and pronounciation are very different.After that, the students get tired and feel do not relax while learning process because teachers uses improvised media or monotonous method in reading activity on learning process in the classroom caused by the lack of available facilities and adequate of time. The last, The situations or learning circumstances is a very big influence in the continuity of teaching and learning activities (KBM), the effects of the existing environment greatly affect the ability of every student, but in here, teaching and learning environment do not make students interested in subject of material because the teacher only arranges the same technique.

According to curriculum book of SMPN 4 Kota Tangerang, this school has minimum mastering (MMC) score, or as we know kriteria ketuntasan minimum (KKM) in English subject which is 70 (seventy). In fact, the students' ability on reading comprehensionare still low. Supporting by English teacher who informed the researchers, from of the many students there were some students who did not reach the KKM.

Especially in the curriculum 13, the teacher only uses teaching resources or materials that are available and provided by the school. It is not bad ways but the students should 
Globish (An English-Indonesian journal for English, Education and Culture

Vol. 10, No.2, July 2021,

P-ISSN: 2301-9913, E-ISSN: 2597-9132

DOI: http://dx.doi.org/10.31000/globish.v7i2

guarantee that they would be interested, and motivated in learning process. An appropriate material will support success in the process and the achievement of learning objectives. The best material can help that students easy to understand in reading and also can improve their knowledge. Moreover, every student will love English lesson which they previously considered very difficult. A best material is also able to influence and change the pattern of improvement of each child's abilities. There are some materials that can be used to teach reading comprehension, such as actual objects, models, authentic material, projector, slides, flashcard, and so on. However the researchers suggest to help students comprehend of reading to increase their ability by authentic material. It was alternative in solve the many problems, this material can beassisted and modified the manner of learning students. As, it is stated by Guariento W and Morley J (2001) said that authentic material can be used in the class especially at the level of the post-intermediate by being able to select text to reach the students in terms both of skills and capacity recent growth, and range of recent languages.

According to Brown (2001), authenticity and meaningfulness are advanced important, because the ability of students about abstract thinking always developed. The teacher brings the material carefully and precisely. The teacher provides positive motivation that learning is easy and fun for students in learning process. To make the students get ideas from what they read, the teacher should create comfortable material in classroom on reading process.There are many ways we can do to make comfortable material in classroom, such as: making or searching authentic materials based on own experience or the others interesting teaching materials and so on.

From the explanation above, the researchers would conduct the research entitles "The Effect of Authentic Materials on the Ninth Grade Students' Reading Comprehension at SMP Negeri 4 Kota Tangerang".

\section{THEORITICAL FRAMEWORK}

\section{A. Theorical Description}

\section{Reading}

\section{a. Definition of Reading}

Discussingabout what reading comprehension is, it is better to discuss the definition of reading itself to achieve effective understanding.Reading is receptiveskill in language that has very important to build mastery of language and one of ways to learning language success. According to Harmer (2001, p. 199) states"Receptive skills are the ways in which people extract meaning from the discourse they see or hear". So that, reading is puposeful activity to find, get and understand the content or information in a written materials.

On the other hand, Harmer (2007) stated that the process of reading is effective for language proficiency, at least that process gives students ability to comprehend what they read and also can build or add of new vocabulary knowledge, spelling, and writing. So, as a reader should have good skills to be able to accept ideas and information.

Brown (2004) defines in foreign language learning, reading as a skill for readers to get message and also the most important skill for benefit in all context of educational. That means, reading is much needed activity while the first stage to get information or meaning depends on the context the reader need. 
Vol. 10, No.2, July 2021,

P-ISSN: 2301-9913, E-ISSN: 2597-9132

DOI: http://dx.doi.org/10.31000/globish.v7i2

Moreover, Grabe and L.Stoller (2001) stated that reading is the process by which readers need to improve abilities as well as such as; understanding of word recognation, build of vocabulary, gramatical awareness, ways of reading cited by (Celce-Murcia, 2001, p.188).Hence, that reading needs many process with an ability to draw meaning from the text.

From the explanation above, there are a lot of definitions of reading. Reading is an activity to see and understandfrom a writing. It also a process of understanding an implicit intention based on text. It can be concluded that reading is a complex process to understand means or ideas and get information from the written material.

\section{b. Definition of Reading Comprehension}

Instudents enviroment of English especially reading, they have to see and find the symbol or information from the text. According to Grabe and L.Stoller (2001) stated that reading comprehenson is process understanding of relationship about interaction of massage in the text cited byCelce-Murcia (2001, p.188). In an action of agreeing what is seen in reading, so that is called comprehension.

Based on Samuels in (2001, p.169) states, "Reading comprehension is a process in which the reader constructs meaning using as the building materials the information on the printed page and the knowledge stored in the reader's head" cited by (Duke and Person, 2001, p.423).Accordingly,McNamara (2007)stated that comprehension related to the skill to get outside the words, agree of ideas and the corellations in every message of the text.

Futhermore, Blachowick and Olge (2008) stated that best comprehenders have studied that they have manage of the reading devolopment, then in the process, comprehension is demanding important approaches. From statement above, it is clear that comprehension is very need to achieve reading better.

Moreover, Kaschak, et. al. (2009) cited by Wagner, Schatschneider, and PhythianSence (2009, p.4) states "The idea that an understanding of complex (and abstract) concept is rooted in bodily interactions in the world is an important component of the embodied approach to language comprehension".They added that reading comprehension as interactive process, when the understand of meaning in the text will affect the perception of the reader.Hedgock (2009) justify that reading comprehension also as complex construct can build the skill to explain the prominent idea in one or more sentence of a text, replay questions about details, represent vocabulary, exactly in read and so on.

In conclusion, reading comprehension refers to process of the reader ability for getting information, idea, mean and all about from the text. Reading comprehension is also a process that builds on the relationship between the text that contains information about what the reader gets.

\section{c. The Strategies of Reading Comprehension}

According to Blackhowicz and Ogle (2008) stated there are big strategies for reading comprehension. The first, these strategies below, who rely on the readers involved (knowingly or unknowingly) :

1) Previewing the text by looking at the chapters, the sketchs, the graphics, and other relevant items.This purpose to start and build ideas, concept, and related remembrance and experience. 
Globish (An English-Indonesian journal for English, Education and Culture

Vol. 10, No.2, July 2021,

P-ISSN: 2301-9913, E-ISSN: 2597-9132

DOI: http://dx.doi.org/10.31000/globish.v7i2

2) Predicting from the preview itis previously known about about the subject, composition, or category that can help the reader for understanding. This previewing also helps the reader to buils on environment knowledge about both the subject and category of reading material.

3) Setting purpose for reading by asking questions that necesity to be replayed.

4) Choosing an appropriate strategy that estabilished on indicator and questions(example from a book ("I'm going to skim this quickly to find out where he is," or "I am going to read the summary of this physics chapter first to get the overall gist"

The second, these below some strategies involved comprehenders follow during process reading :

1) Checking understandingby keeping step of the summary of the material. This can be done by summarize,draw, and ask, "Does this make sense?"

2) Integrating the new information with what is already known by creating relations and conclusions,constract images, or adding explanation what the author says.

3) Monitoring comprehension by using all indicating system to discover out unidentified words, by certain what is necessary in the reading material, and by using "fix-up" strategies (such as rereading and reading ahead) when complication are confront.

4) Continuing to predict/question, to clarify those complication and replay or reformulate the questions, and to ask new questions.

The last, these below some strategies involved comprehenders employ after process reading :

1) Summarizing and synthesizing what has been readby dealing with the plot or main ideas, and also the authors' aim and mindset. This builds a meaning for the whole that beyond the meaning ofthe personal parts read (tittle, category, etc).

2) Responding approriately: individually, critically/acutely, and creatively.

3) Reading multiple sources and cross-checking information useful or creating other relations across texts and knowledge types.

4) Checking for fulfilment of the purpose of reading.Were questions replayed? Was the author's presentation competence? Does the reader necessity or fascination to read or learn more or search further for information?

5) Using what is read in some operation

Based on explanation of the strategies for reading comprehension above, it is very useful in implementation the process of understanding. It is also very much needed and indeed becomes an obligation for every reader to get information which is as clear as possible. Therefore, the reader needs to have a strategy to implement into the process of reading comprehension. In addtion, lots of reading material such as authentic materials like: newspaper, recipes, advertisements and so on that are available and are usually read anytime and anywhere. So, knowing the right reading comprehension strategy will help understand easier and faster.

\section{Authentic Material}

\section{a. Definition of Authentic Material}

In language teaching has at least five significant division: teacher, students, materials, teaching method, evaluation. All parts work together and complement one another in the process of teaching and learning (KBM). Division in language teaching should be suitably in order to reach the teaching purpose, especially about materials. According to Snow (2007) 
Globish (An English-Indonesian journal for English, Education and Culture

Vol. 10, No.2, July 2021,

P-ISSN: 2301-9913, E-ISSN: 2597-9132

DOI: http://dx.doi.org/10.31000/globish.v7i2

stated that many reading learningmaterials are available but the best material is material can attract attention and is easy to apply and understand.Beside that, Kilickaya (2004, p.1) states "Generally, what this means is materials which involve language naturally occuring as communication in native speaker context use, or rather those selected contexts where standard English is the norm: real newspaper reports, for example, real magazine articel, real advertisement, cooking recipes, horoscopes, etc".

On the other hand, Laniro (2007) stated that Authentic materials are not makedefinitely for using in the classroom, but to used for building great learning tools for students correctly because that material is authentic and it can help students to learn between the classroom and the outside world.Harmer (2007) also added that authentic teks is not create and write for language students, but purpose for any competent users of language. It is very clear that authentic teks can help students learning with interesting way through authentic material.

Howover, Berardor (2006) stated that authentic material must be based on the students need and what students might see such as: when travelling, learning abroad or in applying different context of language outside the classroom. He also added that students might be interect with the concret language. Beside, Jacobson, Degener and Purcell-Gates (2003) stated that authentic material is learning material based on facts or reality that students normally find in their daily lives, it outside learning materials that have been provided by the teacher or the school, such as: textbooks or student worksheet (LKS).So, authentic material can build of students confidence, because the material used is directly related to all activities that the often encounter everyday.

Blachowicz and Ogle (2008)stated that in classroom the esential of materials can build good readers, when in chossen of material shoud be motivating for the reader and construct instructional value.Grabe and L.Stoller cited in Celce-Murcia (2001, p.180) also added that textin material for academic purposes must be attractive and coherently.Beside that, Brown (2001) stated that authentic language is very need, so must be more than clear.Therefore the selection of authentic materials is really considered.

Guariento and Morley (2001) also stated that at now the use of authentic teks is treated as one way for supporting or improving students' motivation in studying.Without realizing it, in the modern era authentic materials have developed and influenced students because authentic materials make students more interested than thick books that are made for the learning process.

Based on some explanation above of what authentic materials is. Authentic material can help as a media approach that can build the level of interest of students in the context of comprehension in reading.It can be concluded that authentic material is a learning media based on real conditions in all action of daily life, which provide learners indirectly and unwittingly.Therefore, authentic material is also able to explore and develop students' ideas in understanding English from words to sentences that can be related to their previous knowledge.

\section{b. The Advantages and Disadvantages of Authentic Materials}

Authentic material has advantages and disadvantages as other material that has been or has not been applied in teaching.According to Kilickaya (2004) stated that some main advantages from authentic materials as below:

1) They are having positive effect of students' motivation. 
Globish (An English-Indonesian journal for English, Education and Culture

Vol. 10, No.2, July 2021,

P-ISSN: 2301-9913, E-ISSN: 2597-9132

DOI: http://dx.doi.org/10.31000/globish.v7i2

2) They are contributing authentic cultural information.

3) They are bringing to concrete language.

4) They are relating more closely to students' needs.

5) They are supporting a more creative approach to teaching.

Martinez (2002) in Rajabi and Farahian (2016) definesthere are a few point regarding disadvantages of authentic material including:

1) Usually just only a best knowledge of ethnic background in a text when reading.

2) Usually many of structure combine together.

3) Creating lower levels problems when decoding the texts.

For more clearly of comparison about the advantages and disadvantages of using materials. Berardor (2006, p. 65) states with tables coloumas below:

\section{c. Type sources of Authentic Materials}

According to Gebhard (1996) cited in Oura (2001, p.67-68), stated that many source can used to teacher for teaching, in his examples as bellow:

1) Authentic Listening/ Viewing Materials --TV commercials, quiz shows, cartoons, news clips, comedy shows, movies, soap operas, professionally audio-taped short stories and novels, radio ads, songs, documentaries, and sales pitches.

\section{Picture 2. 1}

\section{Authentic Listening/Viewing Material}

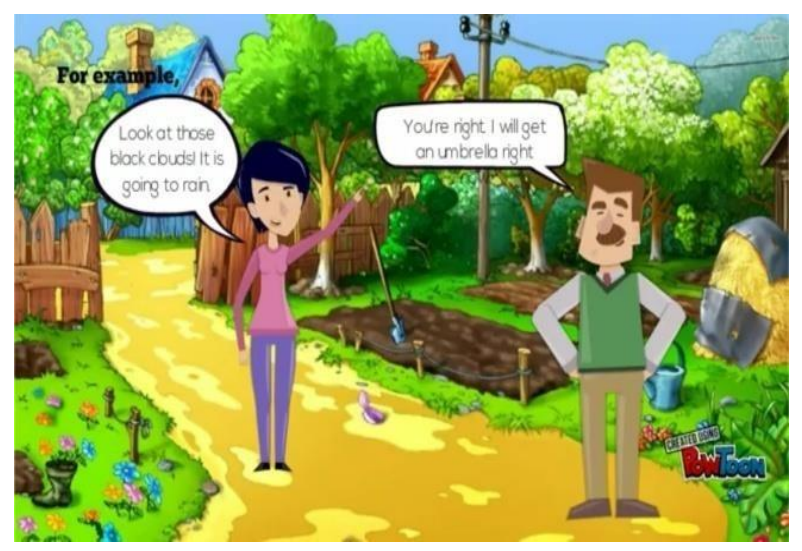

2) Authentic Visual Materials - slides, photographs, paintings, children's artwork, stickfigure drawings, wordless street signs, shilhouettes, pictures from magazines, ink blots, postcard pictures, wordless picture books, stamps, and x-rays.

\section{Picture 2. 2}

\section{Authentic Visual Material}


Vol. 10, No.2, July 2021,

P-ISSN: 2301-9913, E-ISSN: 2597-9132

DOI: http://dx.doi.org/10.31000/globish.v7i2

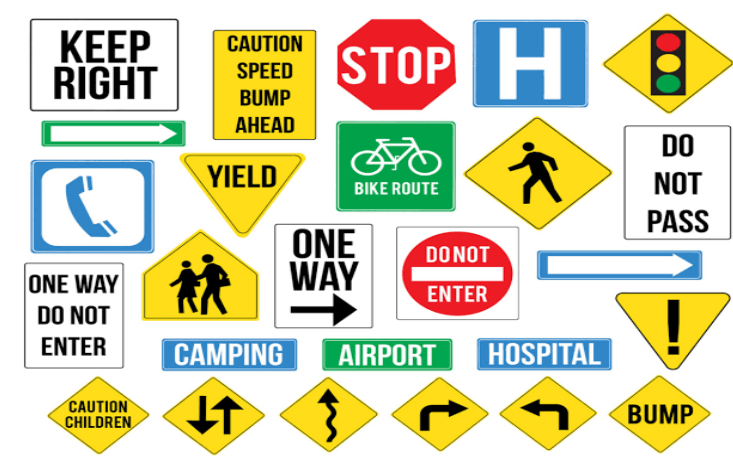

3) Authentic Printed Materials - newspaper articles, movie advertisements, astrology columns, sports reports, obituary columns, advice columns, lyrics to songs, restaurant menus, street signs, cereal boxes, candy wrappers, tourist information brochures, university catalogs, telephone books, maps, TV guides, comic books, greeting cards, grocery coupons, pins with messages, and bus schedules.

Picture 2. 3

\section{Authentic Print Material}

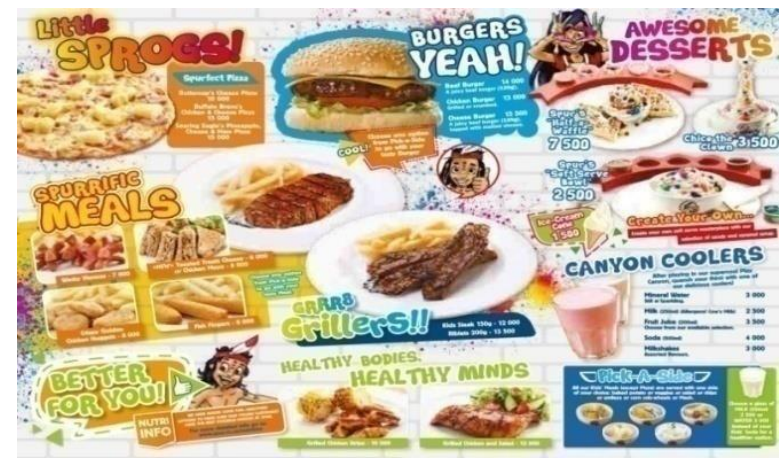

4) Realia ("Real World" objects) Used in EFL/ESL Classrooms - coins and currency, folded paper, wall clocks, phones, hallowen mask, dolls, and pupets, to name a few. (Realia are often used to illustrate points very visually or for role-play situations.

Picture 2. 4

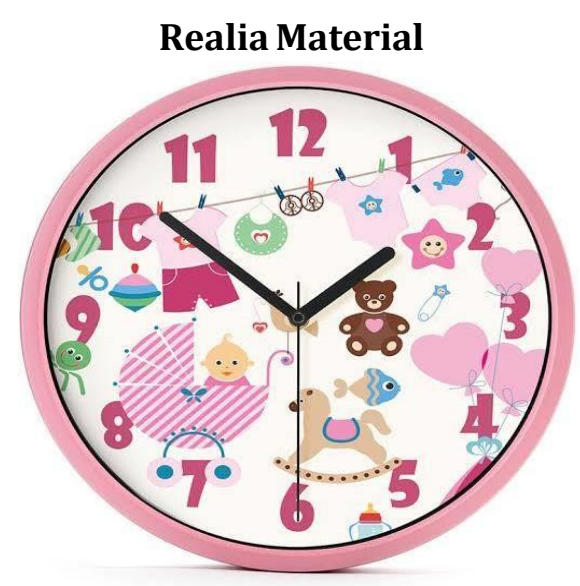


Vol. 10, No.2, July 2021,

P-ISSN: 2301-9913, E-ISSN: 2597-9132

DOI: http://dx.doi.org/10.31000/globish.v7i2

In addtion, Laniro (2007) stated that authentic material have two main categories; Print and auditory. Types of authentic print material such as: Utility bills, packing slips, order forms, ATM screens, ATM receipts, Web sites, Street signs, coupons, traffic tickets, greeting cards, calendars, report cards, TV guides, food labels, magazines, newspapers. Types of autentic auditory materials include: Phone messages, radio broadcast, podcasts, e-book, movies, videos and DVDs, Television programs.

All examples above, there are still many other materials belonging to type authentic listening/ viewing materials, authentic visual materials, authentic printed materials, realia ("Real World"objects) or authentic auditory materials. The researchers chose to use recipes on magazine either food, because usually every student always wants to know various ways to find out various kinds of activities such as making a cake or something else. This authentic materials are also often found, they are read and even they practice directly in real conditions and this process can build their understanding in learning, especially reading comprehension of the text relating to it.

\section{d. The Use of Authentic Materials in Reading Class}

To avoid and minimize the weakness of authentic material, as a teacher need to consider and pay attention on the selection of the use of authentic material that will be applied in learning because unapproriate selection of material will affect the results of the expected achievement or learning objectives. Acoordingly, Nutall (2000) cited in Berardor (2006) gives three main criteria in choosing authentic materials for using in the classroom:

1) Suitability of Content

This is the important part in choosing material, when the material in reading should be interest, motivate and concrete to the students needs.

2) Exploitability

This part correlation with the material, how the text can be used to build students achievment as a reader.

3) Readability

This part very needs to asses the right level in the right students. When this part refers to difficulity of the text and can for drawing the corellation between amount of vocabulary and structure contained in the text

He also purpose some question which are used as based to check before choosing and using authentic materials, as below:

Table 2. 1

Important Factors in Choosing Authentic Material

Important Factors in Choosing Authentic Reading Material

Suitability of $\quad$ Does the text interest the students?

Content

Is it relevant to the student's need? 


\begin{tabular}{|l|l|}
\hline \multirow{7}{*}{ Exploitability } & $\begin{array}{l}\text { Does it represent the type of material } \\
\text { that the student will be use outside of } \\
\text { the classroom? }\end{array}$ \\
\hline $\begin{array}{l}\text { Can the text be exploited for teaching } \\
\text { purpose? } \\
\text { For what purpose should the text be } \\
\text { exploited? } \\
\text { What skills/strategies can be developed } \\
\text { by exploiting the text? }\end{array}$ \\
\hline Readability & $\begin{array}{l}\text { Is the text too easy/difficult for the } \\
\text { student? } \\
\text { Is it structurally too } \\
\text { demanding/complex? }\end{array}$ \\
$\begin{array}{l}\text { How much new vocabulary does it } \\
\text { contain? Is it relevan? }\end{array}$ \\
\hline Presentation & $\begin{array}{l}\text { Does it "look" authentic? } \\
\text { Is it "attractive"? } \\
\text { Does it grab the student's attention? } \\
\text { Does it make him want to read more? }\end{array}$ \\
\hline
\end{tabular}

So, the aim of authentic material for teaching reading should be relevant, applicable and matched with necessity or interest of the students. It is also very important to help andto consider the ability level of students. Futhermore, the students can feel comfortable and confident when learning reading using authentic materials.

Thenext step after preparing various aspects that have been considered in choosing authentic material that is right with the learning objectives.The researchers used two stepsby Widyastuti to implementation of authentic materilas in teaching reading comprehension in the class. According to Widyastuti (2017) that are two steps: firstly observation and secondly review activities.

Observation is one of the first steps in connecting teaching material with realworld situations of students. They can find the clue to what they will learn with the steps below:

1. First step (Pre-reading)

Pre-reading is a process prior to learning to read or preparation to read. The purpose of this step is to build and construct students interest and motivation to the topic 
Globish (An English-Indonesian journal for English, Education and Culture

Vol. 10, No.2, July 2021,

P-ISSN: 2301-9913, E-ISSN: 2597-9132

DOI: http://dx.doi.org/10.31000/globish.v7i2

which this step can lead to the perception that is on their minds. This scanning proccess occurs the first time when they see a text to get information about the topic.

2. Second step (While-reading)

While-reading is a process to the building comprehension. The teachercan develop to be makethe students' encourage flexible and active reader. The teacher also should be control the language learning environment and the students will get real world and language how is really used. In a process While-reading many activities can be use, such as: Ask students to skim the main idea, to answer some questions, monitor their understanding, do error correction, clarify and correct students when they give inccorect answer and so on.

Review activities a process or step to help the students for memorize, confidence, and recognize. This process can make students will be more likely to enjoy the exercise and even better retain the information.In review activity or process Post-Reading the teacher can give activities, such as: give students a review topic, the students' goal is to think of any word that associates with the given topic, students to return to the statements, the teacher brings an English language printing/newspaper to class, the teacher asks students to use the internet to reasearch about the picture or information and so on.

\section{RESEARCH METHOD}

In this research, the researchers used Quasi-Experimental with Non-Equivalent Control Group Design, which are devided into two groups, namely experimental class and control class. According to Sugiyono (2017) stated that in this non-equivalent control group design, both of experimental class or control class not selected randomly. Therefore, to get objective results, researchers will give the pre-test and post-test for both class.Test multiple choice from 20 questions that have been tested for validity and reliability before.

After that, the first thing to do is to give a pre-test in both classes. Above all, the researchers gave treatment in the experimental class only by teaching reading comprehension using authentic material, and the control class uses conventional materials, such as: textbooks and students worksheets. After that the researchers returned to post-test in both classes. The difference in this treatment aims to measure and see the effect whether the use of authentic material can be better or otherwise, by looking at the result of the pretest and post-test or the results before and after being given authentic material treatment in reading comprehension.

\section{RESULT AND DISCUSSION}

\section{Result}

The research was done from july to August with fourty minutes in one meeting at SMP NEGERI 4 KOTA TANGERANG, which is located on JL. Mohammad Yamin, Babakan, Kecamatan Tangerang, Kota Tangerang, Provinsi Banten-15118 in academic year 2019/2020. English language material taught in this research is Reading Comprehension. This research used two classes as experimental and controlled class.The 9.3 as experimental class taugh by Authentic material in a process of learning while the 9.4 as controlled class 
Globish (An English-Indonesian journal for English, Education and Culture

Vol. 10, No.2, July 2021,

P-ISSN: 2301-9913, E-ISSN: 2597-9132

DOI: http://dx.doi.org/10.31000/globish.v7i2

taugh by conventional material or a book. In this research, researchers was conducted for eight meetings in experimental and controlled class.

To get the data, the researchers gave the test by instrument with multiple choice questions. The tests are pre-test and post-test, before instrument was used researchers made conducting the validity and reliability. The researchers has given a pre-test at the first meeting or before giving the treatment in both classes as a resolve the students reading comprehension skill. After that, the researchers gave treatment on both class with different materials forlearning activities fromfirst until the last meeting, in class 9.3 used authentic materials and 9.4 used a student's book. At the end, the research conducted the post-test at the last meeting or after finishing treatment on both classes to determine whether there is the significant effect of authentic materials in learning.

Based on the collecting the data, the researchers gave pre-test and post-test on both classes with mulitiple choice questions that had been tested for validity and reliability before and in analyzing the data the researchers used t-test. Hyphothesis test result as the degree of significant $5 \%$ indicates that pre-test done before treatment is $\mathrm{T}_{\text {count }}(1,22982)<\mathrm{T}_{\text {table }}$ 1,992543 , so $H_{0}$ is accepted and $H_{1}$ is rejected or there is no significant effect from experimental class and the controlled class before giving a treatment. It was found that posttest done after treatment is $\mathrm{T}_{\text {count }}(2,24132)>\mathrm{T}_{\text {table }} 1,992543$, so $\mathrm{H}_{0}$ is rejected and $\mathrm{H}_{1}$ is accepted. The result of this research shows that there is significant difference on students' reading comprehension by using authentic materials.

\section{Discussion}

Based on the data and result of research by researchers showed that authentic materials on the nine grade student's reading comprehensioncan help students improve their reading comprehension than students' by using conventional material.Besides that,Jacobson, et. al (2003) stated that authentic material is learning material based on the fact outside learning materials that have been provided by teacher from a book.This achievment can happen because of that authentic material can construct students' comprehend.

In previous research, the researcherss was conducted by using annecdotal text through comic steps, short functional text through text book, picture series and suggesthopedia method as a way to achieve the goal in the students' comprehend. Concerning all of that, then building students' reading comprehension can be done in various ways or aspects of teaching that can affect students' abilities either through material, media, methods or strategies. The most important principle is to make students easier to learn English, especially reading. As is known, some students find it difficult to understand what they are reading. So, it is very important for researchers to find the right and appropriate way.

According to the description above it shows that if the teacher uses authentic material in teaching reading comprehension is a good choice to do, in order to make students active and interactive in teaching and learning process. This strangthens the theory suggested by Guarento and Morley (2001), stated that nowdays the use authentic material is treated as one way for supporting or improving students' motivation in studying, especially in reading.

Based on the testing hyphothesis as the degree of significant $5 \%$ indicates that pre-test in before treatmentis $\mathrm{T}_{\text {count }}(1,22982)<\mathrm{T}_{\text {table }} 1,992543$, so $\mathrm{H}_{0}$ is accepted and $\mathrm{H}_{1}$ is rejected or there is no significant effect from experimental class and the controlled class before giving a 
Globish (An English-Indonesian journal for English, Education and Culture

Vol. 10, No.2, July 2021,

P-ISSN: 2301-9913, E-ISSN: 2597-9132

DOI: http://dx.doi.org/10.31000/globish.v7i2

treatment. Where post-test in after treatment is $\mathrm{T}_{\text {count }}(2,24132)>\mathrm{T}_{\text {table }} 1,992543$, so $\mathrm{H}_{0}$ isrejected and $\mathrm{H}_{1}$ is accepted or there is significant effect from experimental class and the controlled class after giving a treatment by using authentic material in learning process.

The researchers concludes that the learning process should be more creative to raise up students' enthusiasm in learningreading.It is known that language learning is about exploring many things such as ideas of comprehend text meaningfully and increase reading knowledge as well.

\section{CONCLUSION}

Based on the calculation of data and result, the researchers concluded that there was an effect between students' reading comprehension taught by using authentic material and conventional material.In the average score of pre test in experimental class is 73,1579 and 68,6842 of controlled class. The average scoreof post-test in experimental class is 80,2632 and 73,4211 of controllled class. It means that the average score increase in experimental class by using authentic material.

Hyphothesis test result as the degree of significant $5 \%$ indicates that pre-test in before treatmentis $\mathrm{T}_{\text {count }}(1,22982)<\mathrm{T}_{\text {table }} 1,992543$, so $\mathrm{H}_{0}$ is accepted and $\mathrm{H}_{1}$ is rejected or there is no significant effect from experimental class and the controlled class before giving a treatment. Where post-test in after treatment is $\mathrm{T}_{\text {count }}(2,24132)>\mathrm{T}_{\text {table }} 1,992543$, so $\mathrm{H}_{0}$ isrejected and $\mathrm{H}_{1}$ is accepted or there is significant effect from experimental class and the controlled class after giving a treatment by using authentic material in learning process.

It means that there is difference of students' reading comprehension in experimental class and controlled class. In other word, authentic material give effect for students' comprehension in reading and also can make student interested in reading their classroom or outside class room without feel bored or afraid to do mistake.

\section{REFERENCES}

Anjani, S. (2014). The Effectiveness of Using Authentic Materials Towards Students' Reading Comprehension of Short Functional Texts.Jakarta: Syarif Hidayatullah State Islamic University of Jakarta.

Anshory, M. (2014). Information Center: Kata Kerja Operasional (KKO)Kurikulum 2013). Retrieved on December, 07, 2018. http://ans29.blogspot.com/2014/04/kata-kerjaoperasional-kko-kurikulum.html?m=1.

Asriani, T. (2015). The Effectiveness of Suggesthopedia on Students' Reading Comprehension in Narrative Text. Jakarta: Syarif Hidayatullah State Islamic University of Jakarta.

Asrul, A. R., Rosnita. (2014). Evaluasi Pembelajaran. Bandung: Citapustaka Media.

Badan Standar Nasional Pendidikan (BSNP). (2006). Standar Isi Untuk Satuan Pendidikan Dasar dan Menengah: Standar Kompetensi dan Kompetensi Dasar SMP/MTS. Jakarta. 
Globish (An English-Indonesian journal for English, Education and Culture

Vol. 10, No.2, July 2021,

P-ISSN: 2301-9913, E-ISSN: 2597-9132

DOI: http://dx.doi.org/10.31000/globish.v7i2

Baugh, A. C.\& Cable T. (2005). A History of the English Language. Fifth Edition. London: Pearson Education.

Berardor, S. A. (2006). The Use of Authentic Materials in The Teaching of Reading. The reading Matrix, 6(2).

Blachowicz, C., \& Ogle, D. (2008). Reading Comprehension: Strategies for Independent Learners. New York: The Guilford Press.

Brown, H. D. (2001). Teaching by Principles: An Interactive Approach to Language Pedagogy. Second Edition. White Plains, NY: Longman. P.

.(2004). LANGUAGE ASSESMENT Priciples and Classroom Practices. New York: Pearson Education.

Canadian Language Benchmarks. (2015). Developing a Receptive Task: Levels of Comprehension and Question Types. Retrieved on December, 3, 2018.https://www.google.com/url?sa=t\&source=web\&rct=j\&url=https://realizeforu m.ca/wp-content/uploads/2017/04/Handout-6.2-Levels-of-Comprehension-andQuestiontypes 2015.pd .pdf\&ved=2ahUKEwiSr804qZPgAhWDfX0KHZkVC38QFjAAegQIARAB \&usg=AOvVaw3c1maRxE7ZkvHgeLD wHZd.

Celce-Murcia, M. (2001). Teaching English as a Second or Foreign Language. Third Edition. United Stated: Heinle ELT.

Dakowska, M. (2005). Teaching English as a Foreign Language.Warszawa: Wydawnictwo Naukowe PWN.

Davenport, T.R. (2007).Mastering the Critical Reading Test.Wiley, Hoboken.NJ: Canada

Duke \& person. (2001). Reading Comprehension: Strategies That Work. Retrieved on March, 22 , 2018. https://www.google.co.id/url?sa=t\&source=web\&rct=j\&url=https://www.hand2min d.com/pdf/miriam/grades 1 2.pdf\&ved=2ahUKEwjMzpbGlozaAhWMYo8KHWmGAG 8QFjACegQICRAB\&usg=AOvVaw2zzjzgGbTZuVb37fwngHEN.

Elka, B, R. (2015). The Effec of Using Picture Series on Students' Reading Comprehension on Narrative Text. Jakarta: Syarif Hidayatullah State Islamic University of Jakarta.

Grabe and L.Stoller. (2001). Reading for Academic Purposes: Guidelines for the ES/EFL Teacher. In Celce-Murcia, M. (Ed.),Teaching English as a Second or Foreign Language (P. 188). Third Edition. United Stated: Heinle ELT.

Guariento, W \& Morley, J. (2001). Text and task authenticity in the EFL classroom. ELT Journal of Oxford Univeristy Press, 55/4, 347.

Harmer, J. (1998). How to Teach English. Malaysia: Longman. .(2001). The Practice of English Language Teaching. Third Edition. America: Longman. 
Globish (An English-Indonesian journal for English, Education and Culture

Vol. 10, No.2, July 2021,

P-ISSN: 2301-9913, E-ISSN: 2597-9132

DOI: http://dx.doi.org/10.31000/globish.v7i2 .(2007).How to Teach English. Second Edition. China: Longman.

Hasibuan, I. (2014). Model Pembelajaran CTL (Contextual Teaching and Learning). logaritma, 2/1, 2-3.

Hedgcook, J. S \& Ferris, D. N. (2009). Teaching Reader of English. New York: Routledge.

Hudson, 2007, p. 34. In Carreas, Sosa, and Cardozo, (2017). Researching into the effects of L1 glosses on undergraduates' reading comprehension. In Banegaz, López-Barrios, Waigandt. (Ed.),Authentic in ELT (P. 41). Descarga: Archivo Digital.

Jacobson, E., Degener, S., \& Purcell-Gates, V. (2003). Creating authentic materials and activities for the adult literacy classroom: A handbook for practitioner. NCSALL teaching and training materials, Boston, MA: NCSALL at World Education.

Kilikaya, F. (2004). Authentic material and cultural content in EFL classrooms. The Internet TESL Journal, 10/7, 1.

Laniro, S. (2007). Authentic Material. Retrieved on December, 04, 2018. https://www.google.com/url?sa=t\&source=web\&rct=j\&url=https://www.calproonline.org/documents/AuthenticMaterialsFinal.pdf\&ved=2ahUKEwjLl LU2JngAhUM 3o8KHUpNCtEQFjAAegQIAhAB\&usg=AOvVaw0NlO2SyD8rVyUhs3AbQMNO.

McNamara, D. S. (2007). Reading Comprehension Strategies: Teories, Interventions, and Technologies. New York: Lawrence Erlbaum Associates.

Model Pembelajaran Inovatif Untuk Pembelajaran. (2018). Retrieved on January, 31, 2019. https://anekamodelpembelajaran.blogspot.com/2016/09/model-pembelajaranctl.html?m=1.

Oura, Gail. K. (2001). Authentic Task-Based Material: Bringing the Real World Into the Classroom. Retrieved on December, 06, 2018. https://www.google.com/url?sa=t\&source=web\&rct=j\&url=http://www.esoluk.co.u $\mathrm{k} /$ calling/pdf/Authentic Task Based Materials.pdf\&ved=2ahUKEwjSKLz3JngAhUKQI8KHdnMCcwQFjAAegQIAxAB\&usg=AOvVaw3TvJpp27bG8e0k67UzF GqD.

Pearson. (2013). Reading: Course Book. Canada:Pearson Canada Inc.

Raihan, C, S. (2017). The Use of Authentic Material in Improving Students' Writing Anecdotal Texts.Banda Aceh: Ar-Raniry State Islmamic University of Darussalam-Banda Aceh.

Rajabi, S., \& Farahian, M. (2016). Developing Authentic L2 Reading Materials. New Trends and Issues Proceedings on Humanities and Social Science, 05, pp 01-09.

Rianti, R \& Soefendi. (2014). IEPC Reading Strategy. Palembang.

Riyadi, E. (2014). Metode Statistika Parametrik \& Nonparametrik: Untuk Penelitian Ilmu-ilmu Sosial dan Pendidikan. Tangerang: Pustaka Mandiri.

Snow, D. (2007).From Language Learner to Language Teacher. China: Longman. 
Globish (An English-Indonesian journal for English, Education and Culture

Vol. 10, No.2, July 2021,

P-ISSN: 2301-9913, E-ISSN: 2597-9132

DOI: http://dx.doi.org/10.31000/globish.v7i2

Sugiyono. (2017). Metode Penelitian: Kuantitatif, Kualitatif, dan R\&D. Bandung: Alfabeta.

Wagner Richard K, Schatschneider C, \&Phythian-Sence C. (2009). Beyond Decoding The Behavioral and Biological Foundations of Reading Comprehension. United State: The Guilford Press.

Widyastuti. (2017). Authentic material and Automaticity for Teaching English. Register Journal-Language \& Language Teaching Journals, 10/1, 2017. 